\title{
MAGYAR REGIONÁLIS BANKKÖZPONTOK FELKUTATÁSA ÉS AZONOSÍTÁSA
}

\author{
(Exploring and Identifying of the Hungarian \\ Regional Bank Centres)
}

\section{WÁGNER ILDIKÓ}

Kulcsszavak:

bankközpont bankrendszer fiókhálózat

A szerzö többféle adat és mutató segítségével próbálta feltérképezni és beazonositani a Budapesten kivüli magyar regionális bank- és pénzügyi központokat. Ennek eredményeként megállapítható, hogy a legnagyobb gyakorisággal az öt vidéki - magyarországi léptékben gondolkodva - nagyvárosban fordulnak elö olyan központi funkciók, amelyek a többi város közul mintegy kiemelik ezen nagyvárosokat. Összességében megállapitható, hogy nemcsak a fejlett piacgazdaságokban, hanem hazánkban is bizonyos alapvetö pénzügyi funkciók és intézményi formák (például bankok) földrajzilag sürübb eloszläsban vannak jelen a gazdasági térben.

\section{Bevezetés}

A fejlett piacgazdaságokban bizonyos alapvető pénzuigyi funkciók és intézményi formák (például bankok) földrajzilag sürübb eloszlásban vannak jelen a gazdasági térben, mint az egyéb, specializáltabb pénzpiaci funkciók és intézmények (például tỏzsdék, kockázati tőketársaságok), amelyekre inkább az erősebb térbeli koncentrálódás a jellemzö. Ugyanúgy, mint más gazdasági ágazatokban, a pénzügyekben is jellemző az agglomerálódás, a fejlỏdési tradíciók és a helyi meghatározottság, illetve az egyes városi centrumokban, régiókban megfigyelhetỏ a történetileg kialakult klaszterképzödés. Ebböl következően a település/városhierarchia nagymértékben pénzügyi hierarchia is egyúttal, így a legtöbb országnak számos regionális és egyegy kiemelkedö nemzeti bank- és pénzügyi centruma van.

A magyar fiókhálózat elmúlt időszaki bővưlését áttekintve megállapítható, hogy a kétszintủ magyar bankrendszer kiteljesedésének „nyertesei” a településhierarchia magasabb fokán álló városok, azaz a főváros mellett a megyeszékhelyek. Jelen tanulmányban a továbbiakban ezen települési szintre (megyeszékhelyek) vonatkozóan végzünk összehasonlító felmérést az alábbi mennyiségi és minőségi ismérvek alapján a lehetséges magyar bank- és pénzügyi kơzpontok azonosítása céljából:

- banki hitelintézetek száma;

- külföldi bankok és egyéb magyarországi képviseletek száma;

- banki hitelintézetek székhelyeinek száma;

- áru/értéktőzsde müködik-e a vizsgált városban;

- bankfiókok száma; 
Wágner Ildikó : Magyar regionális bankközpontok felkutatása és azonositása.

Tér és Társadalom 18. évf. 2004/2. 107-116. p.

108 Gyors ténykép

TÉT XVIII. évf. 2004 — 2

- a bankok szervezeti felépítése, különös tekintettel a bankközpontok, illetve adott területen központi funkciót ellátó fiókok elhelyezkedésére és azok fö funkcióinak tartalmára;

- a pénzủgyi szektorban fogialkoztatottak száma, aránya és változása az elmúit idöszakban (Wágner 2004).

Pénzügyi központok alatt a továbbiakban olyan földrajzilag jól meghatározható helyeket értùnk, ahol magas szintủ bank- és pénzügyi szolgáltatások koncentrálódnak (Wágner 2004). A pénzügyi aktivitást pedig a fentiekben meghatározott jellemzökön keresztül írjuk körül.

\section{Vidéki bankközpontok azonositása}

A vizsgált mennyiségi és minőségi ismérvek alapján megállapítható, hogy a kétszintü bankrendszer elmúlt idöszakban bekövetkezett „kiteljesedése” ellenére a bank- és pénzügyi rendszer erőteljesen főváros-centrikus maradt. Ennek ellenére a fővároson kívül néhány város megerősödése és szerepének növekedése tapasztalható. Hazánk esetében ez az öt vidéki nagyváros (Debrecen, Győr, Miskolc, Pécs, Szeged) bank- és pénzügyi szektorban játszott szerepének felértékelödését jelenti (Wagner 2004). Ezért a továbbiakban ezen vărosok kiemelt vizsgálatával foglalkozunk.

\section{Szervezetek száma, típusa}

Elsőként a banki hitelintézetek székhelyválasztását vizsgáljuk meg. A soproni székhellyel alapított SOPRON BANK Rt.-t leszámítva valamennyi banki hitelintézet székhelye a fövárosban található. A szövetkezeti formában müködő takarékszövetkezetek székhelyei Budapesten kívül helyezkednek el. Önmagában a takarékszövetkezetek ${ }^{1}$ székhelyéúl választott települések azonban nem válnak bank- és pénzügyi központtá, mivel ezen települések gazdaságban betôltött szerepe csekélynek tekinthető olyan föbb mutatók alapján, mint például az 1 lakosra jutó GDP, müködő vállalkozások száma, népesség, más banki és pénzügyi szereplök jelenléte, foglalkoztatottak száma stb. Mindez pedig a takarékszövetkezetek általános stratégiai célkitüzéseivel is összefügg. Ugyancsak nem fordulnak elő a városi rangú telepưlések között külföldi banki székhelyek, illetve nemzetközi szervezetek székhelyei. Tözsdék sem müködnek itt.

2002. végén a banki szereplők száma 28. Ebböl 13-nak van országos kiterjedésú fiókhálózata, amelyek mindegyike az öt vidéki nagyváros (Debrecen, Győr, Miskolc, Pécs, Szeged) mellett további négyben (Kaposvár, Kecskemét, Nyíregyháza, Székesfehérvár) fordul csak elő a leggyakrabban, akár több fiókkal is. A 10 egyéb banki hitelintézet közül a lakossági ügyfelek kiszolgálása céljából létrehozott földhitel- és jelzálogbankok $(3 \mathrm{db})$ mellett a lakás-takarékpénztáraknak $(2 \mathrm{db})$ van 1-1 területi koordinációs vagy tanácsadó irodája szinte kizárólagosan az öt vidéki nagyváros valamelyikében. A bankcsoportokhoz tartozó szereplök a bankok fiókhálózatát, 
üzletkötöket, vagy más értékesítési partnereket vesznek igénybe konkrét üzleti tevékenységük gyakorlása során, így érthetỏ módon a szervezet területi kiépítésére sem került, illetve kerül sor.

\section{Fiókhálózat}

Jelenleg a bankfiókok közel egyharmada található a fövárosban. A megyeszékhelyen található fiókok teszik ki a hálózat másik közel egyharmadát. A megyeszékhelyi átlagos fiókszám 18, ami csak az öt vidéki nagyváros (ahol 23-27 között szóródik a fiókszám), a főváros közelsége, illetve a magasabb arányú külföldi tőkebeáramlás miatt Székesfehérvár (20), továbbá Nyíregyháza (20) esetében magasabb.

A fiókok számában mutatkozó különbség önmagában még nem jelenti a pénzügyi szolgáltatások közötti minőségi különbséget. Hiszen a különbözö településszinten lévő egységekben is ugyanazon szolgáltatásokkal várják a bankok ügyfeleiket. A pénzügyi szolgáltatások értékesítése, a bankok sikeres múködése, piaci részesedésük megtartása/növelése nagymértékben függ attól, hogy mennyire tudják felmérni ügyfeleik preferenciáit, és ehhez milyen mértékben képesek alkalmazkodni. Éppen ezért a bankoknak tisztában kell lenniük a kiszolgálandó piacot alkotó ưgyfeleik föbb jellemzöivel, piaci szegmenseket kell kialakítaniuk, és az egyes szegmensekben alkalmazandó értékesítési stratégiájukat ennek figyelembevételével kell kidolgozniuk.

A piac szegmentálható a termékek/üzletágak alapján. A széles banki termékpalettából adódóan megkülönböztethetö betét-, értékpapír-, lízing-, jelzáloghitel stb. üzletág. A lakossági ügyfelek növekvő igényei miatt azonban eltolódás következett be a termék/üzletágcentrikus szolgáltatásnyújtástól a hosszú távú, ügyfélcentrikus szemléletmód felé, amelynek központi kérdése, hogy adott ügyfél mennyi profitot hoz a banknak. Az IT fejlödése pedig már lehetövé teszi a rendelkezésre álló adatok ügyfélkỏzpontú, ill. kisebb ügyfélcsoportok szerinti feldolgozását, így jellemzöik föbb megállapítását. Ennek alapján általában az alábbi szegmenseket különböztetik meg a bankok: lakossági (retail), vállalati (corporate), illetve önkormányzati ügyfelek. Összességében megállapítható, hogy az ügyfelek számára - az IT fejlödése által lehetôvé vált e-banking ellenére - fontos maradt a gyorsaság és a bank-ügyfél közötti személyes kapcsolat megléte, tekintettel az ügyletek bizalmi jellegére. Utóbbiak kiemelten fontosak a bankhitellel is gazdálkodó vállalatok számára. Éppen ezért érthetö módon, a helyi szinten lévő, megfelelő döntési hatáskörrel felruházott fiókok versenyelönyre tesznek szert a fövárosi központtal és a többi egységgel szemben, az információs aszimmetria csökkenésén keresztül megfelelő bankközi koordináció és egységes területi információszolgáltatás alakul ki a bankon belül, továbbá a fiókok mind aktívabban kapcsolódhatnak be mủködési területükön a források újraelosztásába. Ezen kívül a vállalatok testre szabottabb, ügyfélközpontú kiszolgálása is megvalósulhat.

Mindezt a bankok szervezeti-irányítási felépítésének az 1990-es évek közepétől tapasztalható átalakulása (a centralizálttól a decentralizált modell felé történő elmozdulás) is támogatta, s egy magasabb szervezeti-irányítási koncentráció valósult 
meg, kialakultak a területi bankközpontok. Hangsúlyozni szükséges azonban, hogy a régióközpontok kivétel nélkül a vállalati ügyfeleket kiszolgáló fiókok közül kerültek ki, ami figyelembe véve a hazai bankok vállalatfinanszírozásban játszott meghatározó szerepét nem tekinthető meglepónek²

\section{Szervezeti felépités}

A fiókok mennyiségi vizsgálata mellett célszerủ azok hálózaton belüli szerepének, funkciójának az áttekintése is. Szervezeti-irányítási szempontból hierarchikus (aláfölérendeltségi) viszony jellemzi a több megyét felölelö terület központi fiókjának (ún. régióközpont) és a területen lévő fiókoknak a kapcsolatát. Az egyes bankok szervezeti felépítését megvizsgálva ezen nagyobb összefüggő területekre kezdetben általában az igazgatóság/területi igazgatóság elnevezést használták, 1995/96-tól mindinkább elterjedt a régió/regionális igazgatóság elnevezés ${ }^{3}$. A régiók/regionális igazgatóságok központi fiókjai pedig a régió/regionális igazgatóság központjaivá váltak (a továbbiakban röviden: régióközpont). A régióközpontok az országos központ és a helyi fiók között elhelyezkedve a középszintet jelentik. A következö ábra sematikusan és kissé leegyszerüsítve mutatja be egy hierarchikus fiókhálózat felépítését (1.ábra).

A régióközpont irányítási, szervezési, tervezési feladatokat lát el területére vonatkozóan. Továbbá szakmai felügyeletet gyakorol a régióhoz tartozó fiókok felett. Ezzel egyidejüleg folyamatosan értékeli és koordinálja a fiókok tevékenységét. Nagyobb szervezettel rendelkező bankok esetén adminisztratív feladatokat is ellát a régióközpont (például a fiókoktól összegyüjtött adatok feldolgozását követően adatszolgáltatás a központ felé, portfólió minőségének figyelése stb.). Ez utóbbi a leginkább centralizálható megfelelỏ számítástechnikai háttér esetén. A régióközpont döntési hatásköre termékek árazására, illetve egy ügyféllel vagy ügyfélcsoporttal szembeni kötelezettségvállalásra vonatkozóan kerül meghatározásra konkrét régióvezetőre lebontva. A döntési hatáskör a legtöbb bank esetében abszolutizált, azaz konkrét összegekhez vagy mértékekhez kötött, és bankon belül is eltérés lehet különböző régióvezetők döntési szintjében (ami függ a szakmai tapasztalattól, kapcsolatrendszertől, a régió adottságaitól, az ügyfelek elvárásaitól, a versenytársaktól stb.). Kisebb összegủ banki kötelezettségvállalás esetén egyszemélyi döntéshozatal jellemzö, amikor is az üzleti vezetỏ (fiókvezető, régióvezető) a vonatkozó szabályok betartása mellett hozza meg a kompetenciájába tartozó döntést. Nagyobb öszszeg esetén érvényesül a „négy szem” alapelv: a megfelelő végzettséggel és tapasztalattal rendelkező, döntési kompetenciával felruházott, banki üzleti érdekeket szem elött tartó üzleti vezető jellemzően a tőle elkülönült, független szervezeti egységhez tartozó kockázatkezelővel közösen, konszenzusra törekedve hozza meg döntéseit bizonyos összeghatár felett ${ }^{4}$. Az ügyfelek részére értékesítendő szolgáltatások árazására vonatkozó, régióvezetői hatáskört meghaladó, nagyobb mértékü kedvezmények, illetve standard mértékektől való eltérések döntési szintje azonban Budapest. A régió élén álló régióvezetó gyakorolja a munkáltatói jogot a régióhoz tartozó 
fiókok dolgozói felett. A bankok humánpolitikai gazdálkodása ezt leszámítva azonban alapvetően fővárosközpontú. A régióközpontban szakmai és szakember koncentráció is megvalósul azzal, hogy a vállalati hitelezéssel foglalkozó, felsőfokú végzettséggel rendelkező személyeken kívül a kockázatkezelési szervezeti egységhez tartozó személyek mellett a hiteladminisztrációval és -ellenörzéssel foglalkozó személyek is ezen a szinten vannak jelen. Szervezeten belüli megjelenésük a tágabb értelemben használt pénzügyi foglalkoztatottak számát növelheti.

\section{1. ÁBRA \\ Lehetséges fiókhierarchia \\ (A Possible Branch Hierarchy)}

Felső szint

Középsö szint

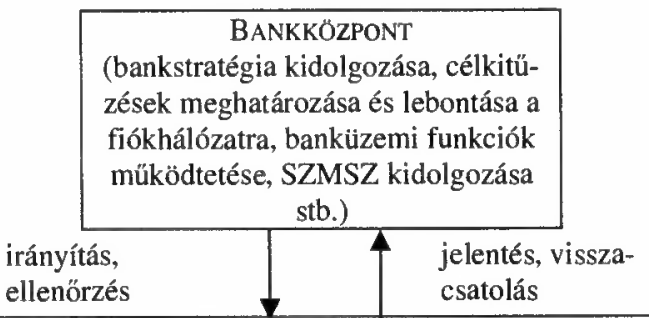

RÉGIÓKÖZPONTOK
(többmegyés területen teljes körủ szolgáltatást nyújtanak a vállalati és lakossági ügyfelek részére + az alárendelt fiókok számára központként funkcionálnak a ledelegált, kapott többletjogosítványokból adódóan)

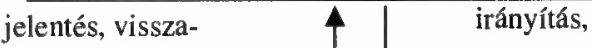
csatolás ellenőrzés

Alsó szint

BANKFIÓKOK (helyi kirendeltségek, amelyek csak elsődleges szolgáltatásokat nyújtanak)

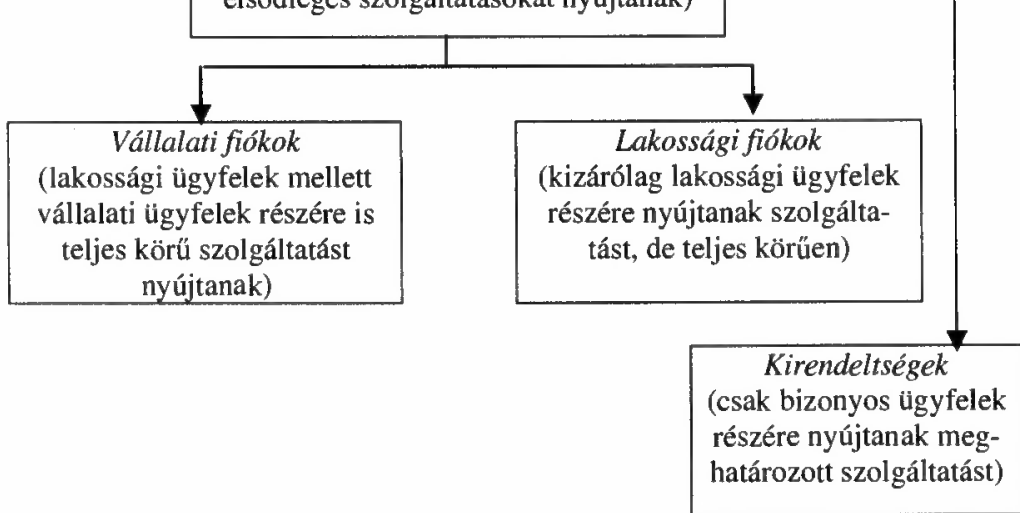

Forrás: Saját szerkesztés. 
Wágner Ildikó : Magyar regionális bankközpontok felkutatása és azonositása.

Tér és Társadalom 18. évf. 2004/2. 107-116. p.

112 Gyors ténykép

TÉT XVIII. évf. 2004 - 2

\section{Konkrét szervezeti felépitések bankonként}

$\mathrm{Az}$ egyes bankok konkrét szervezeti felépítését áttekintve megállapítható, hogy 2002-ben a 28 bankból 13-nak (tehát kevesebb, mint felének) van országos fiókhálózata. A többi jellemzöen csak Budapesten van jelen 1-1 egységgel. A 13 bank közül kettőnél több szintü szervezeti felépítése az alábbi hat banknak van: BB, ERSTE, K\&H, OTP, Postabank és Raiffeisen. A hat bank a teljes fiókhálózat valamivel több, mint $80 \%$-ával rendelkezik. A hat bank régióközpontjai kivétel nélkül megyeszékhelyeken találhatók. Az öt vidéki nagyvárosban (Pécs -5 , Györ -5 , Miskolc - 5, Debrecen - 4, Szeged - 4) legalább négy banknak van régióközpontja, míg a további öt megyeszékhelyi városban (Székesfehérvár - 3, Kecskemét - 2, Salgótarján -2 , Zalaegerszeg - 2, Szombathely - 1) 1-3 banknak van régióközpontja (1. táblázat).

\section{TÁBLÁZAT}

Néhány megyeszékhely összehasonlítása hitelintézeti ellátottság szempontjából, 2003 (The Comparison of Some County Seats by the Supply of Credit Institutions, 2003)

\begin{tabular}{lccc}
\hline \multirow{2}{*}{ Megnevezés } & $\begin{array}{c}\text { Jelenlévő } \\
\text { bankok }\end{array}$ & $\begin{array}{c}\text { Takarékszövetkezeti } \\
\text { székhelyek }\end{array}$ & $\begin{array}{c}\text { Regionális } \\
\text { bankközponti szerep } \\
\text { gyakorisága }\end{array}$ \\
\cline { 2 - 3 } Debrecen & \multicolumn{2}{c}{ száma (db) } & 4 \\
Györ & 13 & 0 & 5 \\
Miskolc & 13 & 1 & 5 \\
Pécs & 13 & 0 & 5 \\
Szeged & 13 & 0 & 4 \\
Magyarország & 13 & 3 & - \\
\hline
\end{tabular}

Megjegyzés: Regionális bankközponti szerepkör alatt értendő: régiós szervezeti felépitéssel rendelkezö bankok közül hánynak van területi központja az adott településen.

Forrás: Magyar Pénzügyi és Tőzsdei Almanach, valamint a Területi Statisztikai Évkönyv éves kiadásai alapján a szerzỏ szerkesztése.

\section{Foglalkoztatottak}

A bank- és pénzügyi szférában foglalkoztatottak ${ }^{5}$ száma és az összes foglalkoztatotton belüli aránya a kétszintủ bankrendszer létrejöttétől kezdve 1996-ig folyamatos növekedést mutatott (2. táblázat). Ezt követöen csökkenés volt tapasztalható számos okra visszavezethetỏen. Így a csökkenés a klasszikusan nem banki szolgáltatási jellegü tevékenységek (például bérszámfejtés és könyvelés, irodaszer beszerzések bonyolítása stb.) „kiszervezése” mellett az összeolvadások, a technológiai fejlődés, valamint új foglalkoztatási formák megjelenésének (például a teljesítményorientáltság érvényesítése céljából egyéni vállalkozók alkalmazása az árukölcsönök bonyolításánál, biztositási ügyleteknél stb.) együttes hatása miatti létszámcsökkentésekkel magyarázható. 
Wágner Ildikó : Magyar regionális bankközpontok felkutatása és azonositása.

Tér és Társadalom 18. évf. 2004/2. 107-116. p.

TÉT XVIII. évf. 2004 @ 2

Gyors ténykép

113

\section{TÁBLÁZAT}

A pénzügyi és összes foglalkoztatott számának alakulása, 1992-2002

(The Development of the Number of Total Employments and in Financial Sector, 1992-2002)

\begin{tabular}{|c|c|c|c|c|c|c|c|c|}
\hline Nemzetgazdasági ág & 1992 & 1996 & 1997 & 1998 & 1999 & 2000 & 2001 & 2002 \\
\hline $\begin{array}{l}\text { Pénzügyi tevékenység } \\
\text { és kiegészítő szolgál- } \\
\text { tatásai (ezer fő) }\end{array}$ & 68,7 & 83,3 & 83,3 & 81,8 & 80,9 & 84,3 & 78,9 & 75,3 \\
\hline $\begin{array}{l}\text { Ebből: Budapest } \\
\text { részesedése (\%) }\end{array}$ & na & 30 & 30 & 30 & 31 & 31 & 32 & 36 \\
\hline $\begin{array}{l}\text { Foglalkoztatottak } \\
\text { összesen (ezer fö) }\end{array}$ & 4025,7 & 3648 , & 3646,3 & 3697,7 & 3811,5 & 3856,2 & 3868,3 & 3870,6 \\
\hline $\begin{array}{l}\text { Ebből: Budapest } \\
\text { részesedése (\%) }\end{array}$ & na & 18 & 18 & 18 & 18 & 19 & 19 & 20 \\
\hline
\end{tabular}

Forrás: Magyar Statisztikai Évkönyv éves kiadásai alapján a szerző szerkesztése.

Hosszú évek után elöször 2000-ben ismét nött a szektor foglalkoztatottjainak száma. A növekedés - amit mindenekelőtt a dinamikusan bővülö lakossági szolgáltatások tettek lehetővé (például jelzáloghitelezés beindulása) - azonban csak átmenetinek bizonyult, hiszen a 2002. év végén a pénzügyi foglalkoztatottak száma az 1996. év alattira csökkent. Utóbbi okaként a fúziók és létszámleépítések folytatódása említhetó.

Összességében az 1996-2002 között bekövetkezett csökkenés ellenére a pénzügyi szektor foglalkoztatásban játszott szerepe lényegesen nem változott, hiszen a pénzügyi szektor változatlanul 2-3\%-kal részesedik az összes foglalkoztatottból. Ez az arány az EU tagországaiban is hasonló nagyságú, 2-4\% közötti. A föváros részesedése a vizsgált időszakban tartósan $30 \%$ körüli, ami meghaladja az összes foglalkoztatott esetén számított 18\%-os arányt. Mindez még inkább aláhúzza a pénzügyi szektor föváros-központúságát.

Összességében tehát a pénzügyi foglalkoztatottak száma 1996-ról 2002-re 13,9\%-kal csökkent. Budapest azonban kivételt képez, mivel ott 7\%-os növekedés tapasztalható. Mindez a főváros pénzügyi központi szerepének további erösödésére enged következtetni. A legnagyobb „vesztesek” a rendszerváltást követően kedvezőtlen gazdasági szerkezetủ megyék közül kerültek ki: Heves, Nógrád és Somogy megye (2.ábra). 
Wágner Ildikó : Magyar regionális bankközpontok felkutatása és azonositása.

Tér és Társadalom 18. évf. 2004/2. 107-116. p.

\section{2. ÁBRA}

A pénzügyi foglalkoztatottak számának relativ változása megyénként, 1996-2002 (\%) (The Relative Change of the Number of Employments by Counties, 1996-2002, \%)

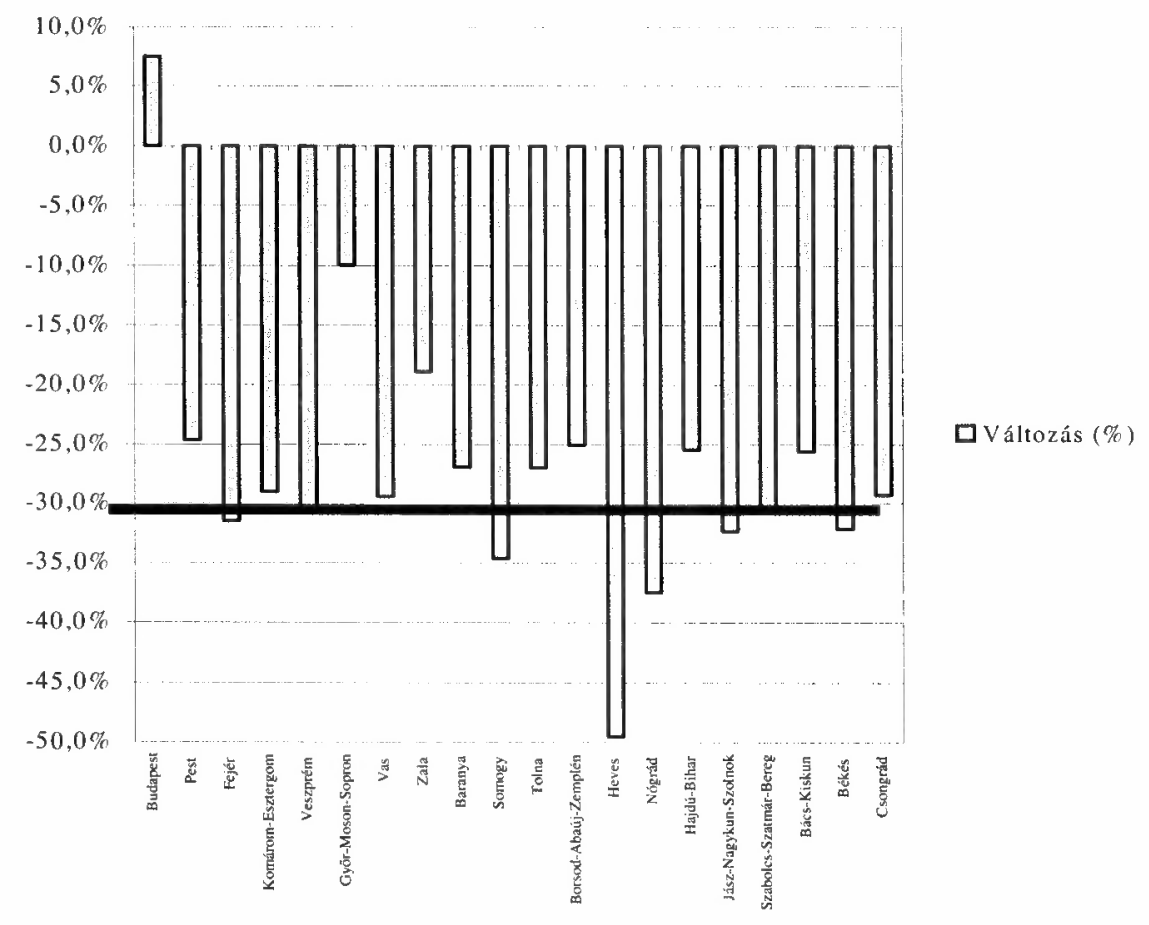

_ Országos átlag $(-13,9 \%)$

Megjegyzés: Az országos átlagot (13,9\%-os csökkenés) egységnek tekintve. Az országos átlag az Y-tengely nulla értékénél jelenik meg.

Forrás: Területi Statisztikai Évkönyv éves kiadásai alapján a szerző szerkesztése.

\section{Összegzés}

A választ keresendö többféle adat és mutató segítségével próbáltuk feltérképezni és beazonosítani a Budapesten kívüli regionális bank- és pénzügyi központokat Magyarországon. Ennek eredményeként összességében megállapitható, hogy a legnagyobb gyakorisággal az öt vidéki - magyarországi léptékben gondolkodva - nagyvárosban fordulnak elő olyan központi funkciók, amelyek a többi város közül mintegy kiemelik ezen nagyvárosokat. Összességében tehát a hazai regionális bank- és pénzügyi központok Debrecenben, Györben, Miskolcon, Pécsett és Szegeden találhatók.

Ezek a városok a kétszintü bankrendszer 1987. évi kialakításakor már elönnyel indultak (historical determinism, path dependence), hiszen a korábbi, szocialista érában tudatos területfejlesztési politika eredményeként Budapest ún. ellenpólus városaiként 
Wágner Ildikó : Magyar regionális bankközpontok felkutatása és azonositása.

Tér és Társadalom 18. évf. 2004/2. 107-116. p.

emelték ki öket a településszerkezeten belül. Kezdeti előnyüket megtartva a bankrendszer kiteljesedése idején, vidéki regionális bankközponttá „nőtték ki” magukat.

A bankközpontok kivétel nélkül az adott régión belül kedvezőbb gazdasági paraméterekkel (GDP-ből való részesedés, 1 före jutó GDP, TOP 200 székhelyeinek száma, közép- és nagyvállalatok székhelyeinek száma, müködő vállalkozások száma, lakosság nagysága, munkanélküliség stb.) jellemezhető megyék megyeszékhely városai közül kerülnek ki, azaz a településhierarchia magasabb fokán álló településsel esnek egybe.

A regionális igazgatóságok térbeli kiterjedése és az általuk ellenőrzött terület nagysága csak többé-kevésbé felel meg a hatályos statisztikai-tervezési régió beosztásnak. Központjaik nagyjából egybeesnek a - hivatalosan ugyan nem deklarált közigazgatási régióközpontokkal (Debrecen, Györ, Miskolc, Pécs és Szeged).

A Budapesten kívül létező, magasabb pénzügyi szolgáltatások nyújtására és nagyobb térség kiszolgálására képes regionális bankközpontokon belül nehéz sorrendet felállítani, mivel a hazai „mezőny” elég kiegyenlített, lényegi különbségek nincsenek közöttük, amint az a 3. táblázatban összefoglalt adatok alapján is jól látható.

\section{TÁBLÁZAT}

Regionális bank- és pénzügyi központok összehasonlitása $(2001,2002)$

(The Comparison of Regional Bank and Financial Centres, 2001 and 2002)

\begin{tabular}{|c|c|c|c|c|c|c|}
\hline $\begin{array}{l}\text { Megne- } \\
\text { vezés }\end{array}$ & $\begin{array}{c}\text { Jelen- } \\
\text { lévö } \\
\text { bankok } \\
\text { száma } \\
\text { (db) }\end{array}$ & $\begin{array}{l}\text { Takarék- } \\
\text { szövetke- } \\
\text { zeti szék- } \\
\text { helyek } \\
\text { száma } \\
\text { (db) }\end{array}$ & $\begin{array}{c}\text { Jelenlévö } \\
\text { nem banki } \\
\text { pénzügyi } \\
\text { közvetítők } \\
\text { száma (db) }\end{array}$ & $\begin{array}{l}\text { Bank- } \\
\text { fiókok } \\
\text { száma } \\
\text { (db) }\end{array}$ & $\begin{array}{l}\text { Pénzügyi } \\
\text { foglalkoz- } \\
\text { tatottak } \\
\text { száma (fó) }\end{array}$ & $\begin{array}{c}\text { Regioná- } \\
\text { lis bank- } \\
\text { központi } \\
\text { szerep } \\
\text { gyakori- } \\
\text { sága }\end{array}$ \\
\hline & 2002 & 2002 & 2002 & 2001 & 2002 & \\
\hline Debrecen & 13 & 0 & 22 & 25 & 1632 & 4 \\
\hline Győr & 13 & 1 & 36 & 27 & 2073 & 5 \\
\hline Miskolc & 13 & 0 & 40 & 24 & 2108 & 5 \\
\hline Pécs & 13 & 0 & 35 & 23 & 1610 & 5 \\
\hline Szeged & 13 & 3 & 37 & 25 & 1573 & 4 \\
\hline $\begin{array}{l}\text { Magyar- } \\
\text { ország }\end{array}$ & 28 & 189 & - & 1168 & 52748 & - \\
\hline
\end{tabular}

Megjegyzés: A pénzügyi foglal koztatottak száma megyére vonatkozó adat.

Regionális bankközponti szerepkör alatt értendö: régiós szervezeti felépítéssel rendelkezỏ bankok közül hánynak van területi központja az adott településen.

Forrás: Magyar Pénzügyi és Tözsdei Almanach, valamint a Területi Statisztikai Évkönyv éves kiadásai alapján a szerzỏ szerkesztése.

\section{Jegyzetek}

\footnotetext{
${ }^{1}$ A 189 szövetkezeti formában műkỏdő hitelintézet Budapesttől eltérő székhelyü, elnevezésük általában utal székhelyưkre és az általuk kiszolgált helyi piac (település és kőzvetlen térsége) elhelyezkedésére.

${ }^{2}$ A lakossági piacon meghatározó szereplőket (OTP, K\&H) leszámítva a lakossági szolgáltatások terén még ma is nagyfokú föváros-központúság van.
} 
Wágner Ildikó : Magyar regionális bankközpontok felkutatása és azonositása.

Tér és Társadalom 18. évf. 2004/2. 107-116. p.

116 Gyors ténykép

${ }^{3}$ A BB a régió szinonimájaként használja a Vállalati Ửzletközpont (VƯK) elnevezést.

${ }^{4} \mathrm{Az}$ összeghatárok bankonként, sőt bankon belưl is eltérnek, azonban 1-1 terủleten lévő fiókok esetében a fiókvezetök/régióvezetök, illetve kockázatkezelök dőntési hatásköre hasonló, mivel nagyobb eltérések versenyhátrányként jelentkezhetnek adott bank számára.

${ }^{5}$ A pénzügyi foglalkoztatottak közé a banki alkalmazottakon kívull a szakosított hitelintézetek, takarékszővetkezetek, lízingtársaságok, egyéb pénzilgyi vállalkozások, biztosítók alkalmazottai, valamint a biztosítási ügynökök és alkuszok, illetve tôzsdei szereplök alkalmazottai is beleértendők. Összességében pénzưgyi foglalkoztatott alatt a „Pénzügyi tevékenység és kiegészítő szolgáltatásai” megnevezésü, $\mathrm{J}$ jelü nemzetgazdasági ágban foglalkoztatott értendő.

\section{Irodalom}

Gál Z. (1998) A pénzintézeti szektor területfejlesztési kérdései Magyarországon. - Tér és Társadalom. 4. 43-68. o.

Wágner I. (2004) A magyar pénzilgyi (közvetítō) rendszer térszerkezeti elemzése nemzetközi kitekintéssel. PhD Kézirat. 